ISSN: 2224-0616

Int. J. Agril. Res. Innov. \& Tech. 8 (1): 14-17, June, 2018

Available online at http:// www.ijarit.webs.com

\title{
STUDIES ON GENETIC VARIABILITY AND INTER-RELATIONSHIP IN BOTTLE GOURD [Lagenaria siceraria (Mol.) Standl]
}

\author{
S. Sultana ${ }^{\mathbf{1}}$, M.S. Rahman ${ }^{2}$, J. Ferdous ${ }^{3}$, F. Ahamed ${ }^{\mathbf{4}}$ and A.K. Chowdhury ${ }^{\mathbf{5}}$ \\ Received 18 December 2017, Revised 4 June 2018, Accepted 26 June 2018, Published online 30 June 2018
}

\begin{abstract}
The genetic parameters were studied to elucidate the genetic variability, correlation and path co-efficient analysis in thirty-nine genotypes of bottle gourd [Lagenaria siceraria (Mol.) Standl] in randomized complete block design with three replications. Observations were recorded for eleven quantitative characters viz., days to first male flower open, days to first female flower open, node number of first female flower, braches plant ${ }^{-1}$, days to harvest, number of fruits plant ${ }^{-1}$, fruit weight, fruit length, fruit girth, 100 seed weight and yield ton ha $^{-1}$. The analysis of variance showed highly significant differences for all the characters studied indicating considerable variability among the genotypes. The highest GCV (35.57\%) and PCV (35.62\%) were observed for fruit length. The differences between GCV and PCV were high for fruit number plant ${ }^{-1}$ and days to first male flower open indicating environmental influences. High heritability associates with high estimates of genetic advance in percent of mean were noted for length of fruit, yield, girth of fruit and number of fruits plant ${ }^{-1}$. It indicated presence of additive gene effect and selection for these traits would be effective. Yield were positively and significantly correlated with fruit weight, 100 seed weight, branch plant ${ }^{-1}$ and number of fruits plant ${ }^{-1}$. Negative associations of yield were noted with days to first male and female flower open, days to harvest and length of fruit. Path analysis revealed that fruits plant ${ }^{-1}(0.93)$ and weight of fruit $(0.467)$ had very high positive effect on fruit yield ton ha-1 ${ }^{-1}$
\end{abstract}

Keywords: Bottle Gourd, Genetic Variability, Genotypic correlation, Path Coefficient

${ }^{1}$ Chief Plant Breeder, Lal Teer Seed Ltd. Gazipur, Bangladesh.

${ }^{2}$ Senior Plant Breeder, Lal Teer Seed Ltd. Gazipur, Bangladesh.

${ }^{3}$ Senior Scientific Officer, Department of Biotechnology, Bangladesh Rice Research Institute, Gazipur, Bangladesh.

${ }^{4}$ Principal Plant Breeder, Lal Teer Seed Ltd. Gazipur, Bangladesh.

${ }^{5}$ Department of Genetics and Plant Breeding, Patuakhali Science and Technology University, Dumki, Patuakhali, Bangladesh.

*Corresponding author's email: salina.sultana@multimodebd.com (S. Sultana)

\section{Introduction}

Cucurbitaceous vegetables are under the largest family Cucurbitaceae consisting of maximum number of edible species in vegetable kingdom. Bottle gourd [Lagenaria siceraria (Mol.) Standl.] is belongs to the family Cucurbitaceae having somatic chromosome number $2 \mathrm{n}=22$. Bottle gourd is gaining popularity as a health food because of its easy digestibility, diuretic and cardiatonic effects (Rahman et al., 2009). Bottle gourd is a cross pollinated crop with large amount of variation for many economically important traits. Bangladesh is one of the Centre's of diversity of bottle gourd endowed with a variety of diverse germplasm. Evaluation of a collection of bottle gourd from different parts of Bangladesh revealed genetic diversity for various quantitative characters. The earliness and yield potentialities of this crop can be improved through an effective breeding program. The available information suggests that modern genotypes often lack additional characters which farmers consider important. Significant genetic variation may exist among bottle gourd genotypes. Some may be superior in certain traits but lacking in other aspects. Their morphological characteristics may also be different; hence, there is a need for detailed study of genetic variation in bottle gourd genotypes in order to generate data. Studies on variability along with heritability and genetic advance helps in predicting inheritance patterns of various characters. Correlation and path-coefficient studies between yield and its components and their relative contributions to yield will be of great value in planning sound breeding program. Therefore, the present investigation was undertaken with a view to work out phenotypic and genotypic coefficient of variation, heritability, genetic gain, association of important genetic traits and path analysis between yield and components could be used as selection indices for identifications of potentially high yielding bottle gourd genotypes. 


\section{Materials and Methods}

The experiment was conducted at the Research and Development Farm of Lal Teer Seed Ltd., Gazipur during the period of 2016 - 2017. The 39 genotypes of bottle gourd were sown in randomized complete block design with three replications. The crop was grown in channel and bed system at a distance of $3 \mathrm{~m}$ between rows and $1 \mathrm{~m}$ between plants. Standard package practices were adopted to raise the crop. Observations were recorded from ten randomized selected plants for the characters viz, days to first male flower open (DMFO), days to first female flower open (DFFO), node number of first female flower (NNFFF), number of branches plant ${ }^{-1}$ (BPP), days to first fruit harvest (DH), fruit weight (FW), fruit length (FL), fruit girth (FG), fruit plant-1 (FPP), 100 seed weight (SW) and yield. Statistical analysis was carried out on 11 quantitative characters (Table 1) by employing SAS (9.2).

\section{Results and Discussion}

The mean sums of squares due to genotypes were highly significant for all the characters subjected to analysis of variance (Table 1).This indicated the presence of considerable amount of variation among the genotypes to carry out further genetic analysis. Joydip et al. (2015) and Damor et al. (2016) also reported similar results. The highest coefficient of variation (17.80\%) was recorded for number of fruits plant ${ }^{-1}$. Therefore, it is possible to select genotype having more number of fruits plant ${ }^{-1}$ from available germplasm. Among the genotypes, the range of variation was observed from 39.53 to 49.47 with mean value of 45.15 for days to first male flower open, 45.80 to 59.67 for days to first female flower open with mean value of 53.27, for node number 15.47 to 24.50 with mean value 19.60 , for branches plant ${ }^{-1} 18.47$ to 31.70 with mean value 24.09 , for days to first harvest 60.63 to 74.67 with mean value 68.39 , for number fruits plant ${ }^{-1} 3.40$ to 8.13 with mean value 5.13 . $1.26 \mathrm{~kg}$ to $1.92 \mathrm{~kg}$ with mean value $1.61 \mathrm{~kg}$ for fruit weight, $14.33 \mathrm{~cm}$ to $49.25 \mathrm{~cm}$ with mean value 30.81 for fruit length, $8.25 \mathrm{~cm}$ to $16.37 \mathrm{~cm}$ with mean value 11.57 for fruit girth, $16.32 \mathrm{~g}$ to $29.22 \mathrm{~g}$ with mean value of 21.97 for 100 seed weight and 17.47 ton to 39.76 ton with mean value 27.43 for yield ha-1. In order to obtain a clear understanding of the pattern of variations, the phenotypic variances have been partitioned into genotypic and environmental variance. Considerable genotypic variances were found in number of node at first female flower open. High heritability associated with high estimates of genetic advance in percent of means (GAPM) was noticed for fruit length, yield and fruits plant ${ }^{-1}$ and fruit girth. It's indicated that presence of additive gene effect and selection of these traits would be effective. The present finding's is supported by Kumar et al. (2011) and Singh et al. (2012).

The length of edible green fruit exhibited highest value of genotypic and phenotypic coefficient of variation (GCV and PCV). Similar findings observed by Kumar and Syamal (2009) and Pandit et al. (2009). High genotypic and phenotypic coefficient of variation was recorded for fruit length, yield, fruits per plant and fruit girth. High heritability coupled with high genetic advance over mean was observed for fruit length, yield, fruits per plant and fruit girth. The individual bottle gourd genotypes, which should desirable mean values in characters like fruit length yield, number of fruits per plant and fruit girth, should be selected, because these characters with high genotypic coefficients of variation, high heritability and high genetic gain are controlled by additive gene action and hence direct selection is effective. Aruah et al. (2012), Kumer et al. (2013) and Joydip et al. (2015) support the present findings. Days to first fruit harvest, days to first male flower open and days to first female flower open registered low genotypic coefficient of variation, high heritability and low genetic gain which indicated the preponderance of non additive gene action and influence of environment.

Table 1. Estimates of Genetic Parameters of 11 characters in 39 bottle gourd genotypes.

\begin{tabular}{cccccccccccc}
\hline Traits & DMFO & DFFO & NNFFF & BPP & DH & FW & FL & FG & FPP & SW & Yield \\
\hline MSG & $24.96^{* *}$ & $37.67^{* *}$ & $13.93^{* *}$ & $24.13^{* *}$ & $26.33^{* *}$ & $0.07^{*}$ & $360.77^{* *}$ & $14.19^{* *}$ & $3.35^{* *}$ & $26.78^{* *}$ & $100.9^{* *}$ \\
\%CV & 4.10 & 3.60 & 8.20 & 6.90 & 2.50 & 16.80 & 3.60 & 8.90 & 17.80 & 1.10 & 4.50 \\
MEAN & 45.15 & 53.27 & 19.60 & 24.09 & 68.39 & 1.61 & 30.81 & 11.57 & 5.13 & 21.97 & 27.43 \\
RANGE & $39.53-$ & $45.80-$ & $15.47-$ & $18.47-$ & $60.63-$ & $1.26-$ & $14.33-$ & $8.25-$ & $3.40-$ & $16.32-$ & $17.47-$ \\
& 49.47 & 59.67 & 24.50 & 31.70 & 74.67 & 1.92 & 49.25 & 16.37 & 8.13 & 29.22 & 39.76 \\
GV & 8.31 & 12.54 & 4.63 & 8.03 & 8.77 & 0.022 & 120.25 & 4.73 & 1.11 & 8.93 & 33.63 \\
PV & 8.35 & 12.58 & 4.66 & 8.06 & 8.80 & 0.023 & 120.26 & 4.74 & 1.12 & 8.93 & 33.65 \\
GCV & 6.38 & 6.65 & 10.97 & 11.75 & 4.33 & 9.32 & 35.57 & 18.76 & 20.47 & 13.61 & 21.14 \\
PCV & 6.60 & 6.66 & 11.02 & 11.79 & 4.34 & 9.32 & 35.62 & 18.84 & 20.66 & 13.61 & 21.15 \\
h2b & 99.52 & 99.85 & 99.54 & 99.64 & 99.66 & 95.65 & 99.91 & 99.54 & 99.06 & 100.00 & 99.96 \\
GA & 5.92 & 7.29 & 4.42 & 5.83 & 6.10 & 0.30 & 22.60 & 4.48 & 2.16 & 6.16 & 11.94 \\
GAM & 13.12 & 13.68 & 22.55 & 24.20 & 8.92 & 18.63 & 73.34 & 38.73 & 42.18 & 28.05 & 43.54 \\
\hline
\end{tabular}

Here, $* \& * *$ indicates $5 \%$ and $1 \%$ level of Significance, MSG=Mean sum of squares due to genotypes, CV=Co-efficient of Variation, GV= Genotypic Variance, PV=Phenotypic Variance, GCV=Genotypic co-efficient of variation, PCV=Phenotypic coefficient of variation, $\mathrm{h} 2 \mathrm{~b}=$ Heritability in broad sense, $\mathrm{GA}=$ Genetic Advance $\mathrm{GAM}=$ Genetic Advance in percent of mean. 
Correlation indicated the mutual relationship among various plant characters and determines the component characters on which selection can be based for genetic improvement of yield. Correlation coefficients at genotypic level were worked out among different characters keeping fruit yield ton ha-1 as dependable variable (Table 2). Yield was positively and significantly correlated with number of branch plant -1 , fruit weight, 100 seed weight and fruits plant ${ }^{-1}$. Number of fruits plant ${ }^{-1}$ recorded highest correlation $(\mathrm{r}=0.884)$ exhibited highly significant and positive correlation with yield. Similar associations of the characters were observed by Aruah et al. (2012), Kumer et al. (2013) and J oydip et al. (2015). However, first female flower, male flower, node number of first female flower, first harvest and length of fruit had negative non significant correlation with fruit yield. Similar findings were recorded by Deepthi et al. (2013), and Janaranjani and Kanthaswamy (2015).

Table 2. Genotypic correlation matrix among different characters in bottle gourd genotypes.

\begin{tabular}{|c|c|c|c|c|c|c|c|c|c|c|}
\hline & DFFO & NNFFF & BPP & $\mathrm{DH}$ & FW & FL & FG & FPP & SW & YIELD \\
\hline DMFO & $0.743^{* *}$ & 0.179 & -0.156 & $0.582^{* *}$ & 0.230 & $-0.464^{*}$ & $0.558^{* *}$ & -0.240 & 0.147 & -0.122 \\
\hline DFFO & & $0.422^{*}$ & -0.201 & $0.792^{* *}$ & 0.183 & -0.230 & $0.390 *$ & $-0.396 *$ & 0.137 & -0.290 \\
\hline NNFFF & & & 0.123 & $0.341^{*}$ & 0.148 & -0.135 & 0.171 & 0.072 & 0.169 & -0.012 \\
\hline BPP & & & & -0.203 & 0.056 & -0.300 & 0.176 & $0.868^{* *}$ & $0.419 *$ & $0.833^{* *}$ \\
\hline HD & & & & & 0.052 & -0.209 & $0.308^{*}$ & $-0.330 *$ & 0.133 & -0.291 \\
\hline FW & & & & & & -0.068 & $0.347^{*}$ & -0.102 & 0.189 & $0.368^{*}$ \\
\hline FL & & & & & & & $-0.879 * *$ & -0.164 & $-0.423^{*}$ & -0.182 \\
\hline FG & & & & & & & & -0.045 & $0.358 *$ & 0.116 \\
\hline FPP & & & & & & & & & $0.306^{*}$ & $0.884^{* *}$ \\
\hline SW & & & & & & & & & & $0.378 *$ \\
\hline
\end{tabular}

*Significant at 5\%level; ** Significant at $1 \%$ level

Table 3. Genotypic path coefficient analysis among different characters in bottle gourd genotypes.

\begin{tabular}{cccccccccccc}
\hline & DMFO & DFFO & NNFFF & BPP & HD & FW & FL & FG & FPP & SW & Yield \\
\hline DMFO & -0.009 & 0.008 & -0.003 & 0.001 & -0.004 & 0.108 & 0.005 & -0.006 & -0.222 & 0.001 & -0.122 \\
DFFO & -0.007 & 0.011 & -0.006 & 0.001 & -0.006 & 0.085 & 0.003 & -0.004 & -0.368 & 0.001 & -0.290 \\
NNFFF & -0.002 & 0.005 & -0.015 & -0.001 & -0.002 & 0.069 & 0.001 & -0.002 & -0.067 & 0.002 & -0.012 \\
BPP & 0.001 & -0.002 & -0.002 & -0.006 & 0.001 & 0.026 & 0.003 & -0.002 & 0.808 & 0.004 & 0.833 \\
HD & -0.005 & 0.009 & -0.005 & 0.001 & -0.007 & 0.024 & 0.002 & -0.003 & -0.307 & 0.001 & -0.291 \\
FW & -0.002 & 0.002 & -0.002 & 0.001 & -0.001 & 0.467 & 0.001 & -0.004 & -0.095 & 0.002 & 0.368 \\
FL & 0.004 & -0.003 & 0.002 & 0.002 & 0.001 & -0.032 & -0.011 & 0.010 & -0.152 & -0.004 & -0.182 \\
FG & -0.005 & 0.004 & -0.002 & -0.001 & -0.002 & 0.162 & 0.010 & -0.011 & -0.042 & 0.003 & 0.116 \\
FPP & 0.002 & -0.004 & 0.001 & -0.005 & 0.002 & -0.047 & 0.002 & 0.001 & 0.930 & 0.003 & 0.884 \\
SW & -0.001 & 0.002 & -0.003 & -0.002 & -0.001 & 0.088 & 0.005 & -0.004 & 0.285 & 0.010 & 0.378 \\
\hline
\end{tabular}

Residual Effect: 0.067 
Association of characters as determined by simple correlation coefficient may not provide an exact picture of the relationship between yield components and yield. The genotypic correlations were portioned into direct and indirect effects through path coefficient analysis to know the relative importance of 12 characters (Table 3 ). Path coefficient analysis (Table 3) revealed that the highest positive direct effects on yield ha-1 were exerted by number of fruits per plant ${ }^{-1}$ (0.93) followed by fruit weight (0.467), first female flower open (0.011) and 100 seed weight (0.01). The contribution of yield components like first female flower open, 100 seed weight, fruit weight and number of fruits plant ${ }^{-1}$ were high in the present study. This is in confirmation with the work of J anaranjani and Kanthaswamy (2015).

Further, node number at first flowering, fruit length, fruit girth and first male flower open, recorded negative low direct effect on fruit yield. In case of indirect effects, number of fruits plant ${ }^{-1}$ has highest indirect effects via number of branch plant $^{-1}$ followed by 100 seed weight. The highest negative indirect effect was recorded by number of fruits plant ${ }^{-1}$ via first female flower open followed by harvest date and first male flower open. The perusal of overall results has impact on yield although simultaneous selection of number of fruits plant ${ }^{1}$, fruit weight, days to first female flower opening and 100 seed weight were the principle component characters, which exhibited high positive direct effects (Kumer et al., 2013, and Husna et al., 2014). The indirect effects of most of the characters were through number of fruits plant ${ }^{-1}$, number of branches plant ${ }^{-1}$ and 100 seed weight will also be useful in bringing higher yield in bottle gourd. Residual effects $0.067 \mathrm{imply}$ that the total genotypic variability in yield has been explained by the characters associated in the study.

\section{Acknowledgement}

We record our sincere thanks to Management of Lal Teer Seed Ltd. for providing us financial assistance during the tenure of the experiment and all those workers in the field who have put in their hard labor and sweat to ensure successful completion of our research program.

\section{References}

Aruah, B.C., Uguru, M.I. and Oyiga, B.C. 2012. Genetic variability and inter-relationship among some Nigerian pumpkin accession
(Cucurbita spp.). Int. J. Plant Breed. 6 (1): 34-41.

Damor, A.S., Patil, J.N., Parmer, H.K. and Vyas, N.D. 2016. Studies on genetic variability, heritability and genetic advance for yield and quality traits in bottle gourd [Lageneria seceraria (Molina) Standl.] genotypes. Int. J. Sci. Envi. Tech. 5 (4): 2301-2307.

Deepthi, B., Reddy, P.S.S., Paratpara Rao, M. and Ashok, P. 2013. Character association and path-coefficient analysis in bottle gourd (Lageneria seceraria L.). Dept. Hort. Dr. YSR Hort. Univ. India. pp. 52-58.

Husna, A., Maih, M.A., Begum, S., Shilpy, S.Z. and Islam, M.R. 2014. Genetic variability, correlation and path-coefficient analysis in bottle gourd (Lageneria seceraria L.). Adv. Agric. Biol. 2 (1): 8-12.

Janaranjani, K.G and Kanthaswamy, V. 2015. Correlation Studies and path analysis in Bottle gourd. J. Hort. 2 (1): 1-4.

Joydip, M., Mangala, T. and Vinod, K.D. 2015. Studies on Genetic variability and trait interrelationship in bottle gourd (Lageneria seceraria L.). Hort. Res. Spect. 4 (1): 34-38.

Kumar, A., Singh, B., Kumar, M. and Naresh, R.K. 2011. Genetic variability, heritability and genetic advance for yield and its components in bottle gourd (Lagenaria siceraria M.). Ann. Hort. 4 (1): 101-103.

Kumar, P. and Syamal, M.M. 2009. Genetic variability, heritability and genetic advance in bottle gourd [Lageneria seceraria (Molina) Standl.]. Indian J . Arid Hort. 4 (2): 95-67.

Kumer, R., Amita, K.D., Dubey, R.B. and Sunil, Pareek. 2013. Genetic variability and path analysis in sponge gourd (Luffa cylidrica Roem.). African J. Biotech. 12 (6): 539-543.

Pandit, M.K., Mahato, B. and Sarkar, A. 2009. Genetic variability, heritability and genetic advance for some fruit characters and yield in bottle gourd (Lagenaria siceraria Molina. Standl.) Genotypes. Acta Hort. 809: 221226.

Rahman, A.H.M.M., Anisuzzaman, M., Ahmed, F., Rafiiul Islam, A.K.M. and Naderuzzaman, A.T.M. 2009. Study of nutritive value and medicinal value of cultivated cucurbits. J . Appl. Sci. Res. 4: 555-58.

Singh, A.K., Pan, R.S. and Bhavana, P. 2012. Correlation and path coefficient analysis for quantitative traits in early season bottle gourd [Lageneria seceraria (Molina) Standl.]. Veg. Sci. 39 (2): 198-200. 